\title{
ANU Student Research Conference: Research paper synopsis
}

\author{
SACHINI MULLER
}

Sachini Muller was a presenter at the 2016 ANU Student Research Conference. At the Digital Technologies and Society session, she presented her paper 'NGOs and the Internet: An Analysis of NGO Web Presence. Her paper has subsequently been revised and published as a Development Policy Centre Discussion Paper.

My decision to apply to present at the 2016 ANU Student Research Conference was born from a desire to go deeper into the world of research, a world I discovered by taking part in the Australian National Internships Program. For the program, I interned at the Development Policy Centre for a semester, spending two days per week researching under the guidance of the centre's Research Officer Ashlee Betteridge and Research Fellow Terence Wood.

The Research Conference was held over two days in mid-July, and was full of very interesting presentations on a large variety of topics, ranging from public policy to the composition of music. In keeping with the theme of Session 5a: Digital Technologies and Society, I presented my research on an analysis of how nongovernment organisations (NGOs) use the internet.

In January 2016, the Sustainable Development Goals came into effect, increasing global interest in the ways in which development is furthered. NGOs are a key part of this, therefore their actions are important as they affect the success of development. While we already knew that NGOs use the internet for a variety of reasons, a systematic analysis of NGO web presence had not, to our knowledge, been previously conducted. We asked the questions: What do Australian aid and development NGOs use their web presence for? Do they try to solicit donations, encourage action, or raise awareness of development issues? I answered these questions by examining the front pages and 'get involved' pages of the NGO websites, and the 20 most recent posts on their Facebook and Twitter pages. From this I then categorised the content into four groups: donate, take action, awareness and other. Finally, I calculated the descriptive statistics for each of the four variables and ran regression analysis on all the data. 
The NGOs included in my analysis were the top 39 internationally oriented Australian aid and development NGOs, or the Australian branch of international NGOs, excluding any NGOs that spent over 25 per cent of their total revenue on domestic projects. I gathered the data over a three-week period, and the NGOs examined covered 92 per cent of the Australian development sector's total revenue.

I found that, on average, the majority of NGO web presence is used to solicit donations: 48 per cent in fact, in comparison to 22 per cent awareness and 9 per cent take action. Take action is by far the smallest slice, and the space devoted to awareness is less than half of what is devoted to seeking donations. This is very different to what we had been expecting, as NGOs put quite a large emphasis on raising awareness and taking action on issues. However, these statistics are averages; there was a lot of variation across NGOs. There was also a lot of variation across different pages-Twitter was the only one that was focused on raising awareness, all three other platforms were used mainly to solicit donations.

When it comes to correlations between characteristics of an NGO and how it uses the internet, there were a number of possible correlations. Although I looked at a number of NGO characteristics, the most important of these findings was the one looking at the proportion of total revenue from the Department of Foreign Affairs and Trade (DFAT) funding. Although we expected there to be a correlation when it came to this characteristic, the direction of the finding was very unexpected. We had thought that increased funding from DFAT would silence NGOs on issues, as encouraging people to take action on issues often involves petitioning or protesting against the government. This would essentially amount to the encouragement of protests against a funder. However, it appears that an increased proportion of total revenue coming from DFAT funding leads to a decrease in attempts to solicit donations, and an increase in attempts to raise awareness of issues. Take action is positive, if anything; however, this relationship was not statistically significant, and therefore not entirely reliable.

While there were a number of findings from my research, the main takeaway point of both my research and my presentation at the Student Research Conference is that, on average, 48 per cent of NGO web presence is used to solicit donations, 9 per cent to take action, and 22 per cent to raising awareness.

Combined with statistics on how NGOs best reach their audience, this research can help them better target their audience. This research gives NGOs a better idea of what they are doing with their websites and social media. Is this in sync with their aims? Have their goals or objectives materialised in their web presence?

Further details regarding this research can be found in a Development Policy Centre Discussion Paper-a refined version of my research, co-authored with Dr Terence Wood. 


\section{Bibliography}

Muller, Sachini \& Wood, Terence. (2016). Aid Online: An Analysis of How Australian Aid NGOs Use the Internet (Development Policy Centre Discussion Paper No. 47). Retrieved from papers.ssrn.com/sol3/papers.cfm?abstract_id=2823263 
This text is taken from The ANU Undergraduate Research Journal, Volume Eight, 2016, edited by Daniel McKay, published 2017 by ANU eView, The Australian National University, Canberra, Australia.

dx.doi.org/10.22459/AURJ.08.2016.03 